Ivona Vrdoljak Raguž, Ph.D.

University of Dubrovnik, Department of Economics and Business Economics, Dubrovnik, Croatia

ivona.vrdoljak@unidu.hr

Zorica Krželj - Čolović, Ph.D.

University of Dubrovnik, Department of Economics and Business Economics, Dubrovnik, Croatia

zkrzelj@unidu.hr

Ivona Milić Beran, Ph.D.

University of Dubrovnik, Maritime Department, Dubrovnik, Croatia imberan@gmail.com

\title{
WOMEN ON CORPORATE BOARDS IN THE REPUBLIC OF CROATIA IN THE CONTEXT OF THE EUROPEAN UNION DIRECTIVES AND NATIONAL POLICIES
}

Received: October 15, 2018

Accepted: December 20, 2018

\section{Abstract}

Gender equality is a very important topic in todays business world that involves the prevention of discrimination and different protection measures for women promotion not only in activities of human resource management such as recruitment, working conditions, training and different benefits, but also in corporate management functions, at board and top level of management. Countries take different approaches in terms of institutional support and setting quotas to increase women presence at boards and top management of the corporations.Across Europe different policies and initiatives are undertaken to increase number of women on corporate boards. In 2011 the Croatian Parliament adopted the National Policy on Gender Equality This policy aims to create a gender balance of supervisory and management board members in the public and private sectors by ensuring that the share of the women to the Act on Gender Equality, does not fall below 40\%. This Policy does not appear to be properly implemented in practice. Statistical data from 2017 shows that share of women on boards of the leading Croatian companies is $17.3 \%$, according to the CROBEX Index which measures the share of women in management positions in the most important companies on the Zagreb Stock Exchange. In 2017 share of women in corporate boards decrease comparing with 2015 and 2016 when it was above 20\%. According to the latest available data from the European Commission in 
April 2016, women are most numerous on corporate boards in France (37.1\%), Sweden (36.1\%), Italy (30.0\%) and Finland (29.8\%). The aim of the paper is to analyse position of women on corporate boards in the Republic of Croatia and do the comparison among Croatia and other EU countries with the critical approach to the analysis of secondary data, European Union directives and national policies.

Keywords: women, corporate boards, the Republic of Croatia, European Union

JEL: M12

\section{INTRODUCTION}

World corporations needto operate in a multinational environment where diversity within corporate boards is dominant and is one of the most importanttopics. According to the Lansing and Chandra diversity is commonly preferable at all levels in a corporation and defined as the composition of different types of people in a corporation or a group of employees. Women on corporate boards can contribute directly and indirectly, directly as leaders, mentors and networking and indirectly by inspiring other women to fight for top management positions and to break the invisible glass ceiling (Terjesen, Sealy, \& Singh, 2009, 320-337). In modern corporations the most important internal mechanisms of corporate governance is the board of directors or management board because it is responsible for strategic management processes in corporation and strategic decision-making. The role of the supervisory board is to advise and monitor top management, and for that purpose the supervisory board is typically consisted of competitive individuals who have the specific skills and all required quality information.

The aim of the paper is to analyse position of women on corporate boards in the Republic of Croatia and do the comparison among the Republic of Croatia and other EU countries with the critical approach to the analysis of secondary data, European Union directives and national policies. This paper provides both descriptive and comparative analysis and is based on the secondary research data, both from internationally and nationally respected researchers and institutions. It is divided into 5 sections. First section is introduction. A review of legislation framework in European Union is demonstrated in section 2, further followed by a legislation framework in the Republic of Croatia in section 3. In section 4, the used methodology and secondary statistical data analysis about women on corporate boards in EU28 and the Republic of Croatia is explained. Section 5 includes a conclusion and discussion with implications and proposals for future research. 


\section{LEGISLATION FRAMEWORK IN EUROPEAN UNION}

The issue of gender diversity has become one of the most important topics for European Commission and has over the last decade tried to reach a sustainable development within the European Union where gender equality is mentioned as one of the European Union's values. The European Union created one internal market where corporations, as well as people, are assured policies of free movement and standardized legislation and rights (European Union, 2017).

In EU a lot of member states have introduced gender quotas on two different ways: a voluntary and mandatory basis. The directive evolved from when the Commission adopted the "Strategy for Equality Between Women and Men 20102015 (European Commission, 2010), which emphasized the promotion of women in the decision-making field. The European Commission in 2012 has proposed legislation with the aim of a $40 \%$ on women on corporate boards in listed corporations (VrdoljakRaguž, 2017, 269-279). These voluntary targets are also to be met in year 2020 (Proposal for a Directive 2012/0299, 2012). All details about quotas in EU28 are presented in table 1.

Table 1. Statistics and national measures in place

\begin{tabular}{|c|c|c|c|}
\hline $\begin{array}{l}\text { Member } \\
\text { State }\end{array}$ & $\begin{array}{l}\text { Share of } \\
\text { women on } \\
\text { boards }\end{array}$ & Quotas in place & $\begin{array}{c}\text { Other national measures in } \\
\text { place }\end{array}$ \\
\hline Austria & $20.1 \%$ & $\begin{array}{c}\text { Yes: only state- } \\
\text { owned companies } \\
\text { ( } 35 \% \text { for } \\
\text { supervisory boards } \\
\text { by 2018). }\end{array}$ & $\begin{array}{l}\text { Self-regulation: The Corporate } \\
\text { Governance Code of } 2009 \\
\text { recommends representation of } \\
\text { both genders in appointments to } \\
\text { supervisory boards. }\end{array}$ \\
\hline Belgium & $26.6 \%$ & $\begin{array}{c}\text { Yes: } 33 \% \text { for } \\
\text { executives and non- } \\
\text { executives in state- } \\
\text { owned and listed } \\
\text { companies-by } 2017 \\
\text { and in listed SMEs- } \\
\text { by } 2019 .\end{array}$ & $\begin{array}{l}\text { Self-regulation: The Corporate } \\
\text { Governance Code of } 2009 \\
\text { recommends that the } \\
\text { composition of a board is } \\
\text { determined on the basis of } \\
\text { gender diversity. }\end{array}$ \\
\hline Bulgaria & $17.9 \%$ & No & No \\
\hline Croatia & $22.2 \%$ & No & No \\
\hline Cyprus & $10.9 \%$ & No & No \\
\hline $\begin{array}{l}\text { Czech } \\
\text { Republic }\end{array}$ & $8.8 \%$ & No & No \\
\hline Denmark & $27.0 \%$ & No & $\begin{array}{c}\text { Boards in state-owned } \\
\text { companies should 'as far as } \\
\text { possible' have an equal gender } \\
\text { balance; a man and a woman }\end{array}$ \\
\hline
\end{tabular}




\begin{tabular}{|c|c|c|c|}
\hline & & & $\begin{array}{l}\text { nominated for every vacancy } \\
\text { (executives and non-executives). } \\
\text { From } 2013 \text { - obligation to all } \\
\text { companies (listed and non-listed) } \\
\text { to self-regulate and set their own } \\
\text { targets. } \\
\text { A company can be fined if it } \\
\text { hasn't set any target figures or } \\
\text { hasn't submitted any reporting. }\end{array}$ \\
\hline Estonia & $8.2 \%$ & No & No \\
\hline Finland & $29.9 \%$ & No & $\begin{array}{l}\text { State-owned companies are } \\
\text { required to have an 'equitable } \\
\text { proportion of women and men'. } \\
\text { The Corporate Governance Code } \\
\text { for listed companies contains } \\
\text { recommendation that 'boards } \\
\text { shall consist of both sexes'. }\end{array}$ \\
\hline France & $37.1 \%$ & $\begin{array}{l}\text { Yes: from } 2011- \\
40 \% \text { by } 2017 . \\
\text { Applicable to non- } \\
\text { executive directors } \\
\text { in large listed and } \\
\text { non-listed } \\
\text { companies. }\end{array}$ & $\begin{array}{l}\text { The AFEP-MEDEF Corporate } \\
\text { Code: recommendation } \\
\text { containing same quotas as in the } \\
\text { Law of } 2011 \text {, applicable to all } \\
\text { board members. }\end{array}$ \\
\hline Germany & $27.2 \%$ & $\begin{array}{l}\text { Yes: from } 2016 \text { - } \\
30 \% \text { for } \\
\text { supervisory boards } \\
\text { of the listed } \\
\text { companies that are } \\
\text { submitted to parity } \\
\text { co-determination } \\
\text { (the roughly } 110 \\
\text { biggest listed } \\
\text { companies). }\end{array}$ & $\begin{array}{l}\text { Other companies that are either } \\
\text { listed or fall under parity co- } \\
\text { determination have to set } \\
\text { individual quantitative } \\
\text { objectives of women on boards } \\
\text { with regard to non-executive and } \\
\text { executive board members and } \\
\text { senior managers below board } \\
\text { level and deadlines to achieve } \\
\text { them. }\end{array}$ \\
\hline Greece & $9.4 \%$ & $\begin{array}{c}\text { Yes, } 33 \% \text { - only } \\
\text { companies fully or } \\
\text { partially owned by } \\
\text { the State. } \\
\text { Applicable to all } \\
\text { board positions } \\
\text { (executives and } \\
\text { non-executives). }\end{array}$ & $\begin{array}{l}\text { Soft positive action measures in } \\
\text { public sector. }\end{array}$ \\
\hline Hungary & $11.2 \%$ & No & $\begin{array}{l}\text { Soft positive action measures in } \\
\text { public sector. }\end{array}$ \\
\hline
\end{tabular}




\begin{tabular}{|l|c|c|c|}
\hline Ireland & $16.0 \%$ & No & $\begin{array}{c}\text { A policy target of } 40 \% \text { female } \\
\text { participation on all state boards } \\
\text { and committees. } \\
\text { Soft positive action measures in } \\
\text { public sector employment. }\end{array}$ \\
\hline Italy & $30.0 \%$ & $\begin{array}{c}\text { Yes: } 33 \% \text { by } 2015 \\
\text { for listed } \\
\text { companies and } \\
\text { state-owned } \\
\text { companies. } \\
\text { Applicable to } \\
\text { management boards } \\
\text { and supervisory } \\
\text { boards (i.e. }\end{array}$ & Yes \\
& & $\begin{array}{c}\text { executives and non- } \\
\text { executives). }\end{array}$ & No \\
\hline Latvia & $27.7 \%$ & $\begin{array}{c}\text { Soft positive action measures in } \\
\text { the public sector. }\end{array}$ \\
\hline
\end{tabular}

Source: European Commission, 2016.

It is visible that research has been made regarding the development of gender equality within corporate boards in general, but not as much in the top management of businesses, in other words, within executive positions (Sjöberg, Drewniok, 2017, 1-64).

\section{LEGISLATION FRAMEWORK IN THE REPUBLIC OF CROATIA}

The primary sources of corporate governance legislation in Croatia are the Company Act, the Audit Act, the Accountancy Act and the Credit Institutions Act. A Corporate Governance Code was adopted by the Croatian Financial Services Supervisory Agency (HANFA) and the Zagreb Stock Exchange in 2007 and revised in 2010. In line with EU legislation, the Code is to be implemented on a "comply or explain" basis (Cigna, Djuric, Kobel, Sigheartau, 2017, 1-15).

According to the EBRD report from 2017 in the Republic of Croatia corporations can decide to be organized under a one-tier or two-tier system. The average size of a board is seven members, which is a manageable size. Boards of the largest companies show relatively high gender diversity, well above the average of EU countries in the EBRD region. Cigna, Djuric, Kobel, Sigheartau (2017) analyzed different corporate governance acts in the Republic of Croatia together with annual reports of listed corporations and concluded that corporations are required to publish their annual reports and the largest listed companies appear to comply well with this requirement. Regarding the different non-financial information in the Republic of Croatia quality of non-financial information is generally good butthere are still some 
key information that is not available (qualification of board members, activities and frequency of meetings of board and committees, and committees' composition). Reporting to the markets and shareholders is one of the most important activities and in the Republic of Croatia is regulated by law and is well implemented in practice. Regarding the audit, the audit committee is in charge of monitoring the robustness of the internal audit function. External auditors do not express opinion on the effectiveness of the internal control system. Insider trading is forbidden and regulated by law. The market capitalization of the Zagreb Stock Exchange is quite high but liquidity appears limited. According to Cigna, Djuric, Kobel and Sigheartau the Corporate Governance Code is an excellent complement to the law. All ten largest listed companies have published a compliance statement, however explanations provided by the companies are not always meaningful and appropriate. The regulator and the exchange have prepared very interesting statistical reports offering general overview of the corporate governance and securities market situation in the country. However, they do not monitor the quality of explanations provided by the companies. (Cigna, Djuric, Kobel, Sigheartau, 2017, 1-15).

\section{WOMEN ON CORPORATE BOARDS IN EU28 AND THE REPUBLIC OF CROATIA}

Over the last two decades so many different scientist and practitioners have investigated the problem of diversity in corporate boards. According to numerous studies, diversity within corporate boards contributes to different benefits in corporation including creativity, greater supervision and monitoring actions, satisfaction among stakeholders and positive business results for the corporation (Billimoria, Wheeler, 2000, Carter, Simkins, Simpson, 2003, 33-53 de Jong, Dejong, Mertens,Wasley, 2005, 473-503, Krishnan, Park, 2005,1712-1720, Bilimoria, 2006, 47-61, Campbell and Mínguez-Vera, 2008, 435-451,Lansing, Chandra, 2012, 3-14). Billimoira and Wheeler have shown in their research that gender diversity on boards contributes to more effective corporate governance through the development and progress concerning board processes, such as improved communication. A few studies have shown that the heterogeneous and diverse boards contribute to a more varied perspective in comparison to homogenous boards, where the latter often have a narrower view (Carter, Simkins, Simpson, 2003, 33-53, Lansing, Chandra, 2012, 3-14). A study made of Campbell and Mínguez-Vera (2008) is focused on decision making processes in corporation. According to them the presence of women on boards may enhance shareholder value since women bring a different perspective to the decision-making process.

This paper examines the women presence in executive positions and CEO positions in the European Union and the Republic of Croatia and is based on the secondary data collected from different databases available at European Commission and Eurostat's websites. Using the statistical data is very important because based on them it is possible to make comparison of the data over time. 


\subsection{Women in European boards}

Secondary data from the EUROSTAT data base show that nearly 7.3 million persons hold managerial positions in enterprises with 10 employees or more located in the countries of European Union (EU): 4.7 million men (65\% of all managers) and 2.6 million women (35\%) (http://ec.europa.eu/eurostat, 2017). It is interesting to analyse also the data of EUROSTAT that show the gender diversity among different countries in EU. Managers are mostly women only in Latvia (53\%) which is followed by Bulgaria and Poland (both 44\%), Ireland $(43 \%)$, Estonia (42\%), Lithuania, Hungary and Romania (all 41\%) as well as France and Sweden (both 40\%). Different situation is in Germany, Italy and Cyprus (all 22\%), Belgium and Austria (both 23\%) as well as Luxembourg (24\%), Croatia (20\%) and Greece (10\%). At EU level $35 \%$ of managers are women (http://ec.europa.eu/eurostat, 2017). In every EU Member State there are differences between women and men in managerial positions concerning wages, male managers earn more than women managers. The gender pay gap in managerial positions is the narrowest in Romania (5.0\%), Slovenia (12.4\%), Belgium (13.6\%) and Bulgaria (15.0\%). In Hungary (33.7\%), Italy (33.5\%) as well as the Czech Republic (29.7\%) female manager earns about a third less than her male colleague, and about a quarter less in countries such as Slovakia $(28.3 \%)$, Poland (27.7\%), Austria (26.9\%), Germany (26.8\%), Portugal (25.9\%), Estonia (25.6\%) and the United Kingdom (25.1\%). (http://ec.europa.eu/eurostat, 2017).

\subsection{Women in Croatian boards}

The Croatian Financial Services Supervisory Agency (HANFA) and Zagreb Stock Exchange for the seventh year in a row, prepared the Annual Corporate Governance Report, in which there is a visible level of corporate governance of the issuer whose securities are listed on a regulatedmarketintheRepublic of Croatia (https://www.hanfa.hr/media/2185/giku-2016-final.pdf).

According to the Annual Corporate Governance Report out of 139 issuers whose shares were listed on the regulated market of the Zagreb Stock Exchange on $31^{\text {st }}$ December 2016, 110 issuers submitted a filled Questionnaire.As of December 31, 2016, most of the board members (38.31\%) had between 45 and 55 years, 33.87\% had between 35 and 45 years, over 55 years had $22.58 \%$ of board members, $5.24 \%$ were less than 35 years of age. Most management members under the age of 35 were in the issuers of real estate and funds (five management members from a total of four issuers). Most top management over the age of 56 was with issuers from the tourism sector (13 management members out of 10 issuers). Most of the members of the board had a university diploma (95.56\%), 3.62\% had a doctorate degree, while $1.21 \%$ had a secondary (high school) or lower qualification. The number of women in Management Board is as following, in 2014, 16.67\%, $14.75 \%$ in 2015 and $15.12 \%$ in 2016. Situation in the Supervisory Board is better if the gender balance is taken into the consideration but still not so good as in some other EU28 
countries especially those with quotas. In 2014 it was $20.62 \%, 20.86 \%$ in 2015 and $20.37 \%$ in 2016 .

According to the data of PayLab and service Mojposaothe biggest differences between women and men wages in the Republic of Croatia are on the managerial level, where women are paid 17\% lower than male (https://www.paylab.com/, https://www.moj-posao.net/).

\section{DISCUSSIONS AND CONCLUSION}

This paper focuses on the women on boards in listed corporations in EU28 and the Republic of Croatia. It contributes to the literature that analyses gender diversity in top management. The presented statistical data show us that the women are less then men present in corporate boards so it means in top management positions. Statistical data presented only the largest listed companies in each of the EU28 countries and in the Republic of Croatia. It will be interesting for the further research to include in the analysis countries outside the European Union. Then it will be possible to compare different regions and countries all over the world and get the global picture of the gender equality in corporate boards.

For future studies it will be also interesting to interview women in leading positions so that aqualitative study can be presented. With that kind of study it will be easier to understand all difficulties and obstacles that women have in corporate boards and also to have an explanation about glass ceiling and glass labyrinth in different types of corporations.

The role of female and men managers hasalready changed and is going to change more in the future but to succeed in that aim it is important to change the mind-set according to traditional roles of women in society. Diversity in management is one of the key variables of contemporary management that will be leading the companies to the organizational success.

\section{REFERENCES}

1. Annual Corporate Governance Report, HANFA and Zagreb Stock Exchange, 2016.

2. Bilimoria, D. (2006). The Relationship Between Women Corporate Directors and Women Corporate Officers. Journal of Managerial , 18(1), pp. 47-61.

3. Billimoria, D., \& Wheeler, J. V. (2000). Women Corporate Directors: Current Research and Future Directions In M. Davidsson; R. J. Burk, Women in Management: Current Research Issues (Vol. 2). London: Publisher, Paul Chapman.

4. Campbell, K., Mínguez-Vera, A. (2008). Gender Diversity in the 
Boardroom and Firm Financial Performance. Journal of Business Ethics, 83(3), pp. 435-451

5. Carter, D. A., Simkins, B. J., Simpson, W. G. (2003). Corporate Governance, Board Diversity, and Firm Value. Financial Review, 38(1), pp. 33-53.

6. Cigna, G. P., Djuric, P., Kobel, Y., Sigheartau, A., Corporate Governance in Transition Economies Croatia Country Report, EBRD, 2017, pp. 1-15.

7. de Jong, A., Dejong, D. V., Mertens, G., Wasley, C. E. (2005). The role of self-regulation in corporate governance: evidence and implications from The Netherlands. Journal of Corporate Finance, 11(3), pp. 473-503.

8. European Commission, Strategy for equality between women and men 2010-2015.

9. European Commission, Strategic Engagement for Gender Equality 20162019.

10. https://www.hanfa.hr/media/2185/giku-2016-final.pdf (access on 27 September 2018)

11. https://www.paylab.com/(accessed on 27 September 2018)

12. https://www.moj-posao.net/ (accessed on 27 September 2018)

13. http://ec.europa.eu/eurostat/documents/2995521/7896990/3-06032017-APEN.pdf/ba0b2ea3-f9ee-4561-8bb8-e6c803c24081 (accessed on 25 September 2018)

14. Krishnan, H. A., Park, D. (2005). A few good women - on top management teams. Journal of Business Research, 58(12), pp. 1712-1720.

15. Lansing, P., Chandra, S. (2012). Quota systems as a means to promote women into corporate boardrooms. Employee Relations Law Journal , 38(3), pp. 3-14.

16. Proposal for a Directive 2012/0299. (2012). Improving the gender balance among non-executive directors of companies listed on stock exchanges and related measures. European Parliament and the Council.

17. Sjöberg, K., Drewniok, S., Female presence within executive positions in European companies, The development in the European Union, Jonkoping University, International Business School, master thesis, 2017., pp. 1-64.

18. Terjesen, S., Sealy, R., \& Singh, V. (2009). Women Directors on Corporate Boards: A Review and Research Agenda. Corporate Governance: An International Review, 17(3), pp. 320-337.

19. VrdoljakRaguž,I., Gender diversity in corporate boards in EU: trends and challenges, Polish Journal of Management Studies, 16 (2017), 1: pp. 269279. 